\title{
Duodenum and Ampulla of Vater Neuroendocrine Tumor pT3 TNM Finding \\ v8
}

National Cancer Institute

\section{Source}

National Cancer Institute. Duodenum and Ampulla of Vater Neuroendocrine Tumor pT3

TNM Finding v8. NCI Thesaurus. Code C135069.

Duodenum and ampulla of Vater neuroendocrine tumor invading the pancreas or

peripancreatic adipose tissue. (from AJCC 8th Ed.) 